\title{
Chapter 10 \\ The Labour Market Needs Them, \\ But We Don't Want Them to Stay \\ for Good: The Conundrum of Migrants, \\ Refugees and Asylum Seekers' Integration in Italy
}

\author{
William Chiaromonte and Veronica Federico
}

\subsection{Discussing Migration in a Challenging Economic and Political Landscape}

Over the past 5 years, migration flows have become crucial to alleviate but not completely counter-balance the overall negative demographic balance in Italy. In 2019, according to the National Institute of Statistics (ISTAT), the resident population totalled 60,391,000, while the foreign resident population counted 5,234,000 individuals, representing $8.7 \%$ of the total population. In 2018, nationals have decreased $3.3 \%$, whereas the foreign resident population has increased $17.4 \%$. Moreover, Eurostat confirms that while the Italian population is on average elderly, the foreign population is quite young (the average age is under 34), which means a strong net contribution to the available workforce.

Much has changed in the demography of the country over the last three decades. At the beginning of the 1990s, the foreign population totalled less than one million. In 2019 it is five times more, representing a rise of $405 \%$. From a country of emigration, with the Italian diaspora present in almost every country in the world, Italy has become a country of immigration. This transformation has been relatively abrupt; social, cultural, political, economic and legal categories have struggled to keep pace with the demography. There are critical consequences to this underlying and problematic lack of syntony, which leads to a constant mismatch between (i) social and

This study is the product of common research and long discussions on problems and perspectives of MRA's integration in the complex and fragmented Italian labour market. Nonetheless, W. Chiaromonte is mainly responsible for Sects. 10.3 and 10.5, V. Federico for Sects. 10.1, 10.2, 10.4 and 10.6 .

W. Chiaromonte $\cdot$ V. Federico $(\bowtie)$

Department of Legal Sciences, University of Florence, Firenze, Italy

e-mail: william.chiaromonte@unifi.it; veronica.federico@unifi.it 
economic needs and the legal and administrative instruments to address them; (ii) new cultural perspectives and the public discourse and media frames that should represent and voice those perspectives; (iii) migration numbers and political discourses about them. This chapter discusses how such disparities also permeate the field of labour market integration.

A brief recap of the data on migration and the Italian labour market helps to contextualise the discussion: among the foreign population resident in Italy, EU migrants represent a little more than $30 \%$. The most numerous non-EU nationalities resident in Italy come from Morocco, Albania, China, Ukraine and the Philippines. Over the last decade, the general trend of the legal reason for acquiring the residence permit has been shifting. Residence permits issued for reasons of work represented almost $50 \%$ of the total permits released in 2011, but they have decreased consistently every year, under pressure inter alia of the economic crisis. In 2019 (last available data), rates dropped to little more than 6\%. On the contrary, residence permits for asylum or humanitarian reasons have significantly increased, peaking in 2017 (more than 28\%) and beginning to decrease in 2018 (26.7\%). Nonetheless, the main channel for obtaining the resience permit is represented by family reunification, which consistently represents between $40 \%$ and $45 \%$ of permits granted between 2011 and 2017, and reaches more than 50\% in 2018 .

These data suggest the migration challenge currently faced by Italy is not necessarily a stand-alone state of affairs. The growing presence of foreign populations is more related to a slow process of stabilisation of the migratory phenomena over the recent two decades, rather than current international conflicts or crises. It should therefore be managed in such terms.

Similar to other European countries, migration trends and developments have been influenced by the geographical, economic, political and sociocultural peculiarities of the Italian context in many regards. The geographical position of the Italian peninsula in close proximity to north African coasts plays a significant role. The relevance of the Italian geographical element juxtaposes with some peculiar economic traits. In particular, research emphasizes the link between immigration and the extended informal sector of the country and those of other southern European states (Testaì 2015; Ambrosini 2013). However, the formal sector, with its unmet labour demand, also contributes to attracting foreign workers. Thus, it is not a coincidence that the majority of foreign workers are concentrated in the highly-industrialized and developed northern regions, while only a small quota, mainly seasonal workers, reside in the less-developed and more agriculture-dependant southern regions. Interestingly, foreign workers' participation in Italian economic life remained high even after the economic crisis of 2008. Indeed, it has been shown (Ambrosini and Panichella 2016; Sciarra and Chiaromonte 2014) that the crisis had a lower impact on foreigners' employment rate compared to the employment rate of nationals, except for the sector of manufacturing and construction - even though it should be noted that the crisis enhanced the structural problems of the Italian labour market, such as segmentation, disparities and pay gaps. Moreover, it is important to point out that: "foreign workers are strongly labour-oriented, so that the phenomenon of the so-called 'disheartenment', that is giving up the search for employment, 
is very uncommon. In fact, unemployed foreigners can be constrained to accept the first job they find, under the pressure to maintain themselves and their families and/ or renovate the residence permit" (Italian Ministry of Labour 2017: 41).

It is against this background that the Italian political discourse began to focus on immigration from the early 1990 s, when the number of non-EU newcomers to the country started to increase, which is quite late in comparison with other European countries. Nonetheless, the Italian political discourse caught up with the overall European political trend: it was influenced by significant anti-immigrant narratives, particularly during the pre-electoral periods (Korkut et al. 2013). Under the slogan "Italians First" and the creation of a dangerous equation between immigrants and criminals, echoed by the mainstream media, demands to close borders and progressively reduce migrants' rights have permeated the political arena. Consequently, the politicization of migration featured in all recent national $(2008,2013$ and 2018) and European (2009, 2014 and 2019) elections (Cavallaro et al. 2018).

Overall, the increasingly strident political discourse, together with the negative media representation of migration, have contributed to a deterioration of the Italian attitude toward migrants (Diamanti 2016). Furthermore, scapegoating the "other" for threatening Italian cultural identity, along with Italian social welfare, security and economic stability, has found a fertile terrain in the limited sense of nationhood and belonging that traditionally characterise Italian citizens (Triandafyllidou and Ambrosini 2011). Further, the economic crisis has exacerbated competition for resources, so that "Italians First" slogans have made sense for a growing number of voters (Cavallaro et al. 2018).

Despite this opposing trend, the labour market does need foreign workers and entire economic sectors are heavily dependant on foreign workforce; foreigners also fill societal gaps, first and foremost in the care of children, the elderly and people with disabilities. Moreover, the practical management of migration displays examples of openness and solidarity. Indeed, the migration crisis has shed new light on the long-standing tradition of volunteerism in Italy, fed by a curious interplay between the Catholic Church, trade unions and others secular associations of the left matrix (Ambrosini 2018).

The chapter goes on to discusses the Italian legal framework governing foreign workers' integration into the labour market, workers' rights and guarantees, the enforcement of a complex web of norms and regulations, and finally how the implementation of the legal framework is in tension with the basic principles that ground the Italian legal system. 


\subsection{Labour, Workers' Rights and the Constitution: The Basic Principles}

Historically, Italy has been primarily a country of emigration; this is reflected in the Italian Constitution of 1948, which recognizes the freedom to emigrate (art. 35(4)) and proclaims the freedom to "leave the territory of the Republic and return to it except for obligations defined by law" (art. 16(2)). At the same time, only few and generic provisions have been devoted to the right of asylum and the legal status of foreigners, ${ }^{1}$ and little is stated concerning foreigners' rights. This constitutional gap has been filled over the years by ordinary legislation and the Courts' intervention.

If the Constitution is concise on foreigners' rights, it is more vocal on the value of labour, labour relations and workers' rights. In fact, the constitutional enforcement of the right to work has strongly influenced labour law and its developments (Gaeta 2014) by providing the institutional foundations and reference values of the Italian social market economy, where economic efficiency and social cohesion should coexist. Social rights, recognized in the Constitution alongside civil and political rights, play a fundamental role in enforcing labour-related rights. Social rights are concerned with protection against the material conditions of deprivation that might prevent the individual from meeting his/her fundamental needs. To be fully enforced, social rights require either the provision of public services, delivered by the state or any other public authority (e.g. the right to education, art. 34 Const.), or the regulation of contractual relationships, as is the case with employment relationships (e.g. the right to a decent wage, art. 36 Const.).

The fundamental principles concerning labour laid down in the Constitution are basically all found in the first articles of the Charter. Art. 1.1 affirms that the Republic

\footnotetext{
${ }^{1}$ Art. 10 states that "(2) legal regulation of the status of foreigners conforms to international rules and treaties; [and] (3) foreigners who are, in their own country, denied the actual exercise of the democratic freedoms guaranteed by the Italian constitution, are entitled to the right to asylum under those conditions provided by law." Other pivotal constitutional provisions, nonetheless, contribute enhancing the national standards of foreigners' rights. In particular, art. 117, through which the EU legislation and international treaties signed by Italy acquire "constitutional relevance"; the "personalist principle" of art. 2, according to which "the Republic recognizes and guarantees the inviolable human rights, be it as an individual or in social groups expressing their personality, and it ensures the performance of the unalterable duty to political, economic, and social solidarity", and the equality clause of art. 3 that forbids unfair discrimination and entrenches substantial equality. And indeed, international conventions and jurisprudence (especially the European Convention on Human Rights (ECHR) and the principle of non-discrimination proclaimed by art. 14 ECHR), equality and the personalist principle have been frequently invoked by the Italian Constitutional Court to secure and extend the fundamental rights of foreigners (Corsi 2014, 2018; Carrozza 2016; Biondi Dal Monte 2013; Chiaromonte 2008). In particular, in several decisions the Constitutional Court affirmed that limiting the access to social benefits aimed to satisfy human basic needs only to foreigners with an EC residence permit for long-residents entails an "unreasonable discrimination" between Italian citizens and foreigners regularly residing in Italy. See, amongst the others, the decision of the Constitutional Court No. 187/2010, in which the Court also makes explicit reference to the decisions of the European Court of Human Rights Gaygusuz v. Austria 16.9.96 and Niedzwieck v. Germania 25.10.05
} 
is "founded on labour", recognizing the historical value of labour as a cornerstone of the state, together with the democratic principle ("sovereignty belongs to the people", art. 1.2 Const). Art.s 2 and 3 recognise and guarantee "inviolable human rights, be it as an individual or in social groups expressing their personality", and equality in its broad meaning of formal and substantial equality. Art. 4.1 recognises the right to work for all citizens, establishing the duty of the state to promote conditions enforcing the right to work and to pursue policies aiming to achieve full employment. The Constitution commits the state to ensuring its citizens the right to work primarily through the promotion of full employment; thus, with regard to access to work, citizens take priority over foreigners. The guarantee of the foreigner's rights, here, is therefore limited by the privileged status of the citizen. ${ }^{2}$ Art. 4 provides the legal basis for restrictions on the entry of foreign workers in order to protect Italian nationals and the regular functioning of the domestic labour market. The Constitutional Court - which in fact has occasionally intervened on this topic has supported this reasoning, assuming that it is reasonable to subordinate foreigners' access to employment to the prior recognition of the unavailability of national workforce (decision No. 144/1970 e 54/1979).

Even though the Constitutional Court has often ruled that, despite art. 3 making reference to citizens only, when the respect of fundamental rights is at stake the principle of equality also applies to foreigners, ${ }^{3}$ the Court's argument is more complex than a simple equalization between citizens and foreigners. It instead ascertains the difference between citizens and foreigners: while citizens have an "original" relation with the state, foreigners have a non-original and often temporary relationship. Hence, the different legal status of foreigners may justify a different legal treatment (decision No. 104/1969) with regard to security, public health, public order, international treaties and national policy on migration (decision No. 62/1994), but not with regard to the protection of inviolable rights (decision No. 249/2010) since they belong "to individuals not as members of a political community but as human beings as such". 4

Following the same reasoning, a Constitutional Court's consolidated case-law maintained foreigners' full entitlement to social rights, such as the right to health and healthcare services (decision No. 269/2010) and to "essential social benefits", such as invalidity benefits for mobility, blindness and deafness regardless of the length of the foreigner's residence. In particular, the Court clarified that specific social benefits that constitute "a remedy to satisfy the primary needs for the protection of the human person", have to be considered "fundamental rights because they represent a guarantee for the person's survival". 5 The same argument, coupled with

\footnotetext{
${ }^{2}$ Here, reference is made to foreigner's access to employment in the private sector, since access to employment in the public sector is regulated by specific provisions, which however do not fall within the scope of this study.

${ }^{3}$ See the following decisions of the Constitutional Court: No. 120/67; No. 104/1969; No. 46/1997.

${ }^{4}$ Among the others see Constitutional Court, decision No. 105/2001, No. 249/2010.

${ }^{5}$ Constitutional Court, decision No. 187/2010. See also Constitutional Court No. 329/2011; No. 40/2013, No. 22/2015 and No. 230/2015.
} 
the anti-discrimination principle, permitted the Court to extend some guarantees and (social) rights to undocumented migrants as well.

Alongside these fundamental principles, Title III of the Constitution devotes few articles to economic relations, establishing a rather conspicuous corpus of constitutional principles that labour law and labour policies must respect and enforce. These principles are crucial for the definition of foreign workforce rights and entitlements. First, citizens' priority over foreign workers when it comes to accessing work may be at odds with the provisions of art. 35, according to which the Republic "protects labour in all its forms" without any limitation. This means that, once the foreigner is authorised to work in Italy, the protection of labour "in all its forms" - including precarious or unstable employment - applies regardless of the nationality of the workers, as the Constitutional Court has emphasised (decision No. 454/1998). Therefore, Italian and foreign workers enjoy full equality of treatment (see art. 2.3, of the Consolidated Law on Immigration, Legislative Decree No. 286/1998). The principle of equal treatment has a very wide scope, covering the internal aspects of the employment activity and relationship, as well as all the additional advantages resulting from his/her employment status. Furthermore, art. 35 states that the Republic "provides for the training and professional enhancement of workers", and "encourages international treaties and institutions aiming to assert and regulate labour rights". Moreover - as already mentioned - art.35.4 recognises the freedom to emigrate and ensures the protection of Italian workers abroad.

Art. 36 affirms the worker's right to a fair remuneration that should be sufficient to ensure him/her and his/her families a free and honourable existence. As a further guarantee, the maximum daily working hours and rest days must be established by law, and workers "cannot waive [the] right [to a weekly day of rest and to annual paid holidays]". Special conditions require special attention, and that is why art. 37 guarantees working women in both formal and substantial terms: "women are entitled to equal rights and, for comparable jobs, equal pay as men. Working conditions must allow women to fulfil their essential family duties and ensure an adequate protection of mothers and children". The article also covers minors, whose minimal age for paid labour shall be defined by the law. Moreover, art. 38, while guaranteeing workers the right to social security, commits the state to providing social assistance to those unable to work and without the necessary means of subsistence, as well as providing education and vocational training to people with disabilities.

Finally, art. 39 establishes trade union freedom and the right to collective bargaining; art. 40, ensures the right to strike; art. 41 guarantees the freedom of private economic enterprise, but envisages the limit of the common good and of safety, liberty and human dignity; and art. 46 recognises the right of workers to collaborate in the management of companies.

What emerges from this brief overview is a complete but coherent system of binding norms that on the one hand recognizes the value of labour in its multiple dimensions (the funding element of the Republic, the means of self and family subsistence, but also the instrument of social integration, of self-promotion and locus "where human personality is expressed" (art. 2 Const.)), and on the other hand sets the standards for human dignity in a prime place in the workplace. Unfortunately, 
however, this system does not guarantee per se "labour rights" oriented laws and policies, and even less so when laws and policies target foreigners, as discussed in the next section.

\subsection{Entering the Country and Becoming a Worker: A Difficult Path}

The integration of MRAs into labour market is connected to the progressive tightening of immigration regulation over the last three decades (Colucci 2018, 140 ss.).

Since the 2002 "Bossi-Fini" Law (Law No. 189 of 2002), any new law and regulation in the field of immigration has contributed to the narrowing of access to the country, and making foreigners' legal status increasingly precarious and fragile (see the most recent acts: the "security package" - Law No. 94/2009, Law No. 125/2009 and Law No. 217/2010-; the "Minniti decrees" - Law No. 46/2017 and Law No. 48/2017-; and finally the "Salvini decrees" - Law No. 132/2018 and Law No. $77 / 2019$, as modified by Law No. 173/2020). This has not been without consequences for their integration into labour market.

If we consider employment conditions alone, in principle no subordinate employment contract (as regulated by art. 2094 of the Civil Code) can violate the "golden rule" of the non-derogation in pejus of the law and of collective agreements. Nonetheless, since the 1990s - and particularly following the severe global recession triggered by the 2007 financial crisis - the rate of flexibility allowed in the labour market has grown considerably. This has resulted in a (partial) liberalisation of the labour market, the increasing use of non-standard typologies of contract and, in the attempt to mitigate the impact of growing unemployment, in a simultaneous weakening of the protection traditionally provided to workers. The main and most recent expressions of this trend are embodied in the so-called "Fornero reform" (Law No. 92/2012) and in the so-called "Jobs Act", a composite "package" of Legislative Decrees adopted in 2015.

With particular reference to the condition of foreign workers, we recall that Italian labour law is based on the principle of equal treatment between regular foreign workers and national workers, as well as workers of other EU Member States. The protection of work "in all its forms and practices" (art. 35 Const.) operates regardless of the nationality of the worker, as noted previously. According to the Consolidated Law on Immigration, the foreigner who holds a work permit has the right to receive the very same remuneration, social security and assistance as any Italian worker. On the contrary, undocumented foreigners willing to work can only resort to the shadow economy and the black market. Unfortunately, undocumented stays inevitably lead to irregular work (Calafà 2017), even though some forms of protection also exist in the black market, especially with reference to the remuneration and contributory position of the worker (Chiaromonte 2018, 348 ss.). 
As mentioned, the employment contract involving a foreign worker does not have significant peculiarities. Non-discrimination with respect to other workers is particularly guaranteed (see art. 43, par. 2, letter $e$, Legislative Decree No. 286/1998 and Legislative Decree No. 215/2003), contrary to the access of foreign workers to the national labour market, which has always been subject to specific regulation.

The system of foreign workers' entry to the country is based on the idea of planning incoming migration flows according to national labour market needs through specific legislation (the Decreto flussi) that should determine quotas for regular entry each year (Sciarra and Chiaromonte 2014; Chiaromonte 2016). The Consolidated Law articulates migration policy into two levels. The first level - the cornerstone of Italian migration policy - is represented by a three-year plan (art. 3, para. 1-3), aiming in particular to define the general criteria for the subsequent annual determination of the entry flows and integration measures. The second level consists of the so-called Decreto flussi, or "flows decree" (art. 3, para. 4), which should be issued each year and establishes the exact annual quotas for work purposes.

However, the provisions of the Consolidated Law that regulate the 3-year plan have gone unheeded (the last plan refers to the period 2004-2006). In other words, the sole instrument for determining migration policy and regulating foreign workers' access to the labour market has been the Decreto flussi, a measure conceived to operationalise a mid-term plan, though not to strategically intervene in such a delicate and crucial field as migration. And indeed, it has been issued annually exclusively to allow the entry of seasonal workers, while the same frequency has not been respected for non-seasonal workers and for self-employment. Moreover, rather than determining quotas for new arrivals, the Decreto flussi has become the instrument to annually regularise the position of undocumented migrants already in Italy (the latest regularization, linked to the Covid-19 health emergency, was laid down by Law Decree No. 34/2020).

In addition, recent years have seen a dramatic reduction of the working permits issued annually: from 250,000 permits issued in the frame of the 2007 Decreto flussi to 30,850 in 2020 . The reduction is complemented with a similarly dramatic increase in international protection applications, which indicates a distorted use of international protection regimes by migrants whose migration may not primarily be determined by humanitarian reasons (Chiaromonte 2019, 335 ss.).

Indeed, entering Italy as a foreign worker is not easy: the process of issuing visas, residence and work permits is long and complex. The employer who intends to hire an alien worker, either permanently or on a fixed-term basis, ${ }^{6}$ must apply ${ }^{7}$ to

\footnotetext{
${ }^{6}$ Noticeably, unless the foreign worker has a permit to stay for other reasons compatible with the transformation into a work permit, it is not possible to directly hire undocumented migrants already in Italy, so what happens for them is to set up the whole proceeding as if they were first entering the country.

${ }^{7}$ It is a nominal application, and the employers has to prove also the accommodation facilities and has to commit to pay for the worker's return ticket in his/her country of origin.
} 
the special office for immigration (the so-called Sportello Unico) at the Police Headquarters once they have ensured there are no available workers in Italy.

The work permit should be issued in 60 days, provided it does not exceed the annual quota. The work permit being granted, the Consulate of the foreigner's residence or origin country issues an entry visa, and the worker has 8 days from her/his arrival in Italy to sign the residence agreement for work reasons at the Sportello Unico. Only after this procedure is completed does the Police Headquarters issue the residence permit for work purposes. The duration of the "residence agreement" cannot exceed 9 months for one or more seasonal jobs, 1 year for a fixed-term employment contract, and 2 years for a permanent employment contract.

In the event the worker loses his/her job for whatever reason, he/she can register as unemployed to the employment centre for a period that cannot exceed the duration of the residence permit (art. 22, para. 11, Consolidated Law). The Law does not provide for the possibility of obtaining a residence permit to actively look for a job; moreover, the complex and lengthy proceedings make it difficult for both job seekers and companies to meet their needs of finding a job on the one hand, and ensuring stable workforce on the other.

Beneficiaries of international protection are recognised by unlimited access to the national labour market. On the contrary, asylum applicants are allowed to work only from the sixtieth day from the submission of the application for international protection, if the application has not been processed yet and the delay is not due to the applicant. In any case, the residence permit thus granted cannot be converted into a residence permit for work reasons (art. 22, Legislative Decree No. 142/2015).

Neither European nor Italian Laws envisage the possibility of working for people in repatriation centres or those awaiting a decision of repatriation. Moreover, no specific incentives are provided to access the labour market for: asylum seekers, international protection applicants, refugees and legal economic migrants (without a long-term residence permit). This represents a critical aspect of the Law here, since the conditions for work placement are often disadvantageous due to language barriers, low levels of education, traumatic experiences related to separation from family and country of origin, the cultural gap, and, for asylum seekers and international protection applicants, their transitional legal status. For beneficiaries of international protection and for asylum seekers and international protection applicants, the employment rate 1 year after arrival in an EU country is very low (around 8\%). ${ }^{8}$ On average, between 5 and 6 years are necessary for integration into the labour market of more than half of the refugees and individuals entitled to international protection. However, data for Italy (which does not monitor this phenomenon) are missing.

Furthermore, so far in Italy there has been a lack of specific investment into integration and inclusion programmes, while the relationship between the state and asylum seekers has mainly conformed to welfare assistance types of dynamics.

${ }^{8}$ EU Parliament, Directorate General for Internal Policies (2016:22). 


\subsection{Working to Integrate: Easy to Say, Hard to Do}

Over the past 20 years, public debate about foreigners has been dominated by the insistence that foreign workers are welcome in Italy, as long as they contribute to the wellbeing of the host society and its economy (Ambrosini 2001). Yet, as a matter of fact, the barriers to accessing the labour market remain considerable, and, from a legal perspective, pertain to two different clusters of reasons: a narrow recognition of rights, and the weakness of measures to develop MRAs' capabilities.

First and foremost, the right to work is not universally recognized for all those living in Italy. Entering the country as a worker is difficult, as discussed; obtaining the right to work once in the country for other reasons may also be very hard. Asylum seekers are allowed to work after 60 days from their asylum application, but if they need to receive accommodation facilities, their annual income should not exceed approximately 6000 euro. This forces people to make hard choices, often pushing them to resort to the black or grey labour market. The rigidity of their legal status is a second barrier that blocks full benefit of the right to work. The margin of manoeuvre foreign workers have depends heavily on their entry channel and the legal status they have been allocated: "Each legal status is subject to a number of conditions, which need to be fulfilled in order to obtain a specific set of rights. Conditions to be fulfilled and rights guaranteed vary a lot from one legal status to another. With more than 40 different foreigners' legal statuses, the landscape becomes pretty heterogeneous and labyrinthine" (Federico and Pannia 2019).

Second, while language knowledge is a potent enabler, it becomes a barrier when no learning services are available. Following the Law No. 132/2018, a new tender specification scheme (Capitolato) was adopted by the Ministry of Interior. Under the new Capitolato, only few basic services are provided in CAS (centre for extraordinary reception for asylum seekers), excluding language courses; there are few public language learning facilities for seasonal workers, either. The large majority of language courses are provided by third sector entities, some of which have become proper informal education institutions. Yet, the presence of civil society associations is not homogeneous throughout the country, which entails a highly differenciated offer of opportunities that depends on geography rather than needs.

Third, the problem of recognizing professional qualifications should be noted. Qualifications and training acquired in the country of origin are not easy to officialy recognise in Italy, since long and complicated procedures are generally required. Moreover, applicants and beneficiaries of international protection often do not have certificates issued by their country of origin, meaning they cannot apply for jobs appropriate to their education level (Favilli 2015, 726). This opens the door to another possible enabler to labour market integration that may become a barrier: accessing education and vocational training. Access to schooling and academy is granted to all MRAs, except to undocumented migrants, even though the children of undocumented families are allowed to enter the schooling system. Yet, temporary economic migrants are not allowed to enroll in tertiary education unless they have been in Italy for at least 1 year and obtained a diploma in the country. The same applies to vocational training, with a sole, major problem: likewise language learning opportunities, the new tender specification scheme for CAS provided for by 
Law No. 132/2018 excludes training services. This means that, de facto, organising vocational training within the reception centers has become extremely difficult and should be done at zero cost, which is unrealistic and undermines integration into labour market. Furthermore, the Law No. 132/2018 excluded asylum seekers from the right to be enrolled on the civil registry. This de facto, once again, prevented asylum seekers from accessing a number of social services provided by local municipalities, such as training. The provision has been expunged by the Constitutional Court in a recent decision in July 2020 (No. 186/2020) for the intrinsic inconsistency with the purpose of the law itself, therefore asylum seekers can be enrolled again, and benefit from the related services.

Finally, a full enforcement of the right to work entails the recognition and concrete enactment of a number of social rights as ancillary provision connected to the recognition of the worker, the worker's family and dignity. Housing is one such social right. Art. 40(6) of the Consolidation Law and art. 29 of Legislative Decree No. 251/2007 guarantee refugees the right to access public housing, but public houses are much less than required, therefore, in practice, a widespread recourse to informal settlements is reported amongst refugees. The same applies to long-term economic migrants. Foreigners unable to provide for their housing and subsistence needs have the right to be accommodated in public housing at the same conditions as destitute nationals. However, in the long term, housing is subjected to limitations. In fact, the Consolidated Law on Immigration stipulates that only foreigners holding a EU long-term residence permit or foreign workers with a permit to stay no less than 2 years can have access to public housing accommodation and housing support measures (art. 40 of the Consolidated Law on Immigration). Under the Law No. 132/2018, asylum seekers, who previously could enter the SPRAR system, can only be accommodated in centres of extraordinary reception (CAS) activated by the Prefectures, quite often large facilities, far from workplaces. A new Decree Law No. 13/2020 has readmitted asylum seekers in the SPRAR system (which has been renamed while maintaining the same organising principles), but with a non-priority admission scheme. No access to public housing and housing measures is granted to seasonal workers.

No unemployment benefits are recognised for seasonal foreign workers, and even though asylum seekers formally are recognised, the requirement of 2 years of contributions de facto reduces their opportunities to effectively enjoy this right. All other categories of MRA are entitled to the same treatment as Italian citizens. The case of unemployment benefits clarifies a crucial point underlying our discourse: from a legal perspective, much depends on the foreign worker's legal status, which may become a barrier that blocks their right to work being recognised and enforced, or it may become one of the most potent enablers to their labour market integration.

\subsection{They Should Work as Nationals Do, But This Is Not Always the Case}

In a joint paper of December 2016, the OECD, ILO, the World Bank and the IMF observe that "effective labour market integration is a key factor to enhance the benefits of migration - for both origin and destination countries, but also for the 
migrants themselves. Migrant workers are best protected where the fundamental principles and rights at work are effectively enforced" (OECD, ILO, the World Bank and IMF 2016). What is interesting in this otherwise self-evident statement is the qualification attributed to labor maket integration. There is consensus among scholars, stakeholders and policy-makers that to unleash the potential of MRAs, labour market integration should be "effective", which means allowing foreigners, regardless their status (except from the regularity of their stay), to work as nationals do. In Italy, this entails three dimensions: anti-discrimination measures, contrasting undeclared work and accessing welfare benefits.

\subsubsection{Anti-discrimination Measures}

Italian labour law has no overarching equal treatment provision covering all aspects of employment conditions, but there are specific norms applying to peculiar aspects. Compared to equality, non-discrimination has a narrower and more focused scope, since it only prohibits differences in treatment - between workers and groups of workers - determined by grounds specifically listed by the law. Therefore, diversified treatments in the workplace become discriminatory and illegal only when they are against one of the listed grounds (Barbera and Guariso 2019). Yet, non-discrimination is strongly enforced at the European level (art. 10 TFEU and art. 21, para. 1, Charter of Fundamental Rights of the European Union) and the EU Court of Justice has stated that European anti-discrimination rules shall prevail over any eventual breach entrenched in domestic legislation.

Gender (Legislative Decree No. 198/2006), political opinions and trade union activity (art. 15, Law No. 300/1970), race and ethnic origins (Legislative Decree No. 215/2003), linguistic group and nationality (art. 2, para. 3 and art. 43, para. 2, lett. $e$, Consolidated Law on Immigration), religion, ${ }^{9}$ personal beliefs, disability, age and sexual orientation (Legislative Decree No. 216/2003) are all listed grounds.

Discrimination may be direct or indirect, individual or collective, but not every difference in treatment constitutes discrimination: "In compliance with the principles of proportionality and reasonableness, [...] differences in treatment based on characteristics related to race or ethnic origin do not constitute discrimination [...] if, by reason of the nature of the working activity or the context in which the latter is carried out, such characteristics constitute an essential and decisive requirement for the pursuit of that working activity" (art. 3, para. 3, Legislative Decree No. 215/2003). Furthermore, differences in treatment which - though indirectly discriminatory - are objectively justified by "legitimate aims pursued through appropriate and necessary means" are considered as legitimate (art. 3, para. 4, Legislative

\footnotetext{
${ }^{9}$ With regard to this point, on the sensitive question of whether it constitutes religious discrimination to prohibit an employee from wearing the Islamic headscarf at work see CJEU, 14 March 2017, C-157/15, Achbita; CJEU, 14 March 2017, C-188/15, Bougnaoui.
} 
Decree No. 215/2003). The same applies to religion or belief, disability, age or sexual orientation (art. 3, para. 3 and 5, Legislative Decree No. 215/2003). ${ }^{10}$

A special form of judicial protection is provided in legal cases entailing discrimination (art. 28, Legislative Decree No. 150/2011). This takes the form of the partial reversal of the burden of proof, so that if the worker allegedly discriminated against provides the Court with evidence suitable for establishing - in "precise and consistent" (for discriminations on the grounds of race or ethnic origin) or in "serious, precise and consistent" (for discrimination on the grounds of religion, personal beliefs, etc.) terms - the existence of discriminatory acts, pacts or behaviours, it is up to the defendant employer to prove there has not be any discrimination.

Ordinary judges and the Constitutional Court have only very occasionally intervened in the principle of equal treatment, they have rarely condemned discriminatory treatment of foreigners in the private sector, not because of the judiciary's reluctance but rather because few cases have reached the courts. The most common cases involving discrimination against foreigners brought to the attention of the judges have not been directly concerned with working conditions, but rather with the ban on access to public services, the guarantee of the right to group identity (e.g. the right to speak one's own language) and of the neutrality of the public sphere. ${ }^{11}$ Moreover, most of the decisions involve disputes with the public administration, the so-called "institutional discriminations". This points to the difficulty of intercepting discriminations between individuals (even discrimination at work, for which the prohibition of discrimination has traditionally arisen), where the individual's contractual freedom competes with the principle of equality.

\subsubsection{Contrasting Undeclared Work and Caporalato}

Art. 22, para. 12 of the Consolidated Law on Immigration imposes criminal sanctions $^{12}$ on the employer "who employs foreign workers without a residence permit [...], or whose permit has expired and whose renewal, has not been requested by

\footnotetext{
${ }^{10}$ The parallel with discrimination on the grounds of race and ethnic origin continues with the fact that those differences in treatment that, although indirectly discriminatory, are objectively justified by "legitimate aims pursued through appropriate and necessary means" (art. 3, para. 6, Legislative Decree No. 216/2003) are in any case considered legitimate.

${ }^{11}$ See e.g. the rulings available at the ASGI (Associazione per gli Studi Giuridici sull'Immigrazione (https://www.asgi.it/banca-dati/) database, and Guariso (2012).

${ }^{12}$ The penalties consist of prison sentences of between 1 and 6 years, and a fine of 5000 euro for each worker employed. In cases of particular exploitation of the worker, art. 12, para. 5 of the Consolidated Law also provides for the most serious crime of facilitation of the illegal permanence of the foreigner for the purpose of unjustified profit. The sanctions have been strengthened by the Legislative Decree No. 109/2012, which has transposed Directive 2009/52/EC. The decree provides that the above mentioned penalties are increased by one third or more when the number of employees exceeds three, when they are minors under the working age, or when they are exposed to situations of serious danger, taking into account the characteristics of the services to be provided
} 
law, or has been revoked or cancelled". Legislative Decree No. 109/2012 provides for the extension of criminal liability to legal persons who are responsible for facilitation of illegal immigration (art. 12, Consolidated Law on Immigration).

Moreover, art. 22, para. 5 bis of the Consolidated Law on Immigration authorises the Sportello Unico for immigration to refuse the authorization to work to any employer who in the last 5 years has been convicted for facilitating illegal immigration or emigration, or for crimes related to the recruitment of persons for the purpose of (the exploitation of) prostitution or of minors.

The employer must pay the irregular foreign worker the full wages and social contributions provided for lawful employment for a minimum period of 3 months, unless the employer or the employee prove otherwise (art. 3, Legislative Decree No. 109/2012). However, due to the undesirable consequences, it is very unlikely for the worker to receive what is due before his/her removal, since the emergence of the unlawful presence of the undocumented worker entails her/his voluntary or forced removal, in accordance with the provisions of the Returns Directive (2008/115/EC).

Yet, in the event of severe labour exploitation, charging files against the employer and collaborating with the prosecuting authority grants the undocumented worker a 6-month residence permit, renewable for 1 year or till completion of the criminal proceedings (art. 22, para. 12 quater and quinquies). The provision of a residence permit to the foreigner who is victim of labour exploitation is certainly an important novelty in the Italian legal system, especially in light of her/his subsequent integration into the (regular) labour market. However, Legislative Decree No. 109/2012 has narrowed the typology of "serious labour exploitation".

With regard to the additional administrative and financial sanctions provided by Directive 2009/52/EC against employers who have employed an irregular labour force, no implementation measures are found in the Legislative Decree No. 109/2012. However, precisely these sanctions could potentially play a fundamental deterrent role, since the consequences for employers would be very serious and particularly from an economic point of view. Moreover, Legislative Decree No. 109/2012 does not provide any specific measure against subcontracting, a common phenomenon of the exploitation of undocumented labour.

Concerning the phenomenon of caporalato, Law No. 199/2016, amending art. 603 bis of the Penal Code, introduced new provisions aimed to contrast the widespread and serious phenomenon of illegally recruiting labour through exploiting the worker's condition of need, a phenomenon particularly rooted in the agricultural sector and, more generally, in the agri-food production chain (D'Onghia and de Martino 2018; Chiaromonte 2018; Fanizza and Omizzolo 2018).

The caporalato, which "succeeds" in keeping foreign labour in Italy that would otherwise be expelled, and intercepts the incoming flows attracting new labour force, often involves undocumented migrants, who are further particularly vulnerable. Since reporting to public authorities would lead to those workers'

and the working conditions (art. 22, para. 12 bis). Together with the conviction, the judge also applies the accessory administrative sanction, consisting of the payment of the average repatriation cost of the illegally employed foreign worker (art. 22, para. 12 ter). 
expulsion - except for the already mentioned very few cases for which the law provides for the possibility of issuing a residence permit - they tend not to criticize their situation of exploitation, confirming the well-known difficulties of access to justice for foreigners (especially the undocumented) also with reference to the most serious cases of labour exploitation (the number of complaints is strongly conditioned by their undocumented status, sanctioned by criminal law, of the worker victim of serious exploitation). Therefore, they accept working and living in situations of particular degradation, as well as precarious health conditions, often with limited access to drinking water, basic medical care and decent housing.

The most relevant innovation of the Law No. 199/2016 consists in the identification (art. 603 bis, para. 1) of two distinct criminal conducts: (1) the caporale, who recruits workers (often, but not necessarily, undocumented migrants) for third parties in conditions of exploitation, and taking advantage of their state of need (in this case the crime is that of illegal intermediation and exploitation of labour); and (2) the employer, who hires or employs workers, even without the intermediation of the caporale, subjecting them to conditions of exploitation and taking advantage of their state of need (in this case the illegal intermediation can only potentially occur).

Two elements characterize the criminal conduct of both the caporale and the employer: on the one hand, the exploitation of labour: para. 2 of art. 603 bis identifies the "legal indices of exploitation", most of which refer to the conduct of the employer only, which are grouped into four categories: remuneration, working hours, safety and hygiene at work, and the general working conditions, which means a systematic violation of the "hard core" labour law conditions. On the other hand, is the exploitation of the state of need of the workers. At stake here is the breach of the fundamental value of the human dignity of the worker. Unless the fact constitutes a more serious crime, the caporale or employer is punished with imprisonment from 1 to 6 years, and with a fine from 500 to 1000 euros for each employed worker. Moreover, imprisonment from 5 to 8 years and a fine from 1000 to 2000 euros for each employed worker is given when the acts are committed with violence or threat.

\subsubsection{Access to Welfare Benefits}

Despite the long and rich catalogue of national and supranational regulations enforcing the principle of equal treatment between Italian and EU citizens and extra-EU nationals concerning access to welfare benefits, the most recent legislation has introduced the condition of residence. This means that welfare benefits may be reserved for those who can prove they have resided for a certain period in a given region or in the country. This kind of condition, while not directly discriminatory, can generate indirect prejudice to foreigners' interests (Chiaromonte and Guariso 2019).

The same rationale has inspired anti-poverty measures. The basic income established by Law No. 26 of 2019, for example, targets poor Italians, EU citizens and 
third country nationals with a long-time residence permit, that can prove having spent in Italy at least 10 years and the last two continuously.

The Constitutional Court does not have a unilateral position on the subject. The Court has often adopted the distinction between services directed to meet the fundamental rights and basic needs of the individual, that cannot be conditioned by any long-term residence requirement, and services that, on the other hand, do not address basic needs and can be restricted, but restrictions and conditions should not be arbitrary and unreasonable, as is the case for restrictions based on the public spending reduction (inter alia, judgments n. 187/2010, 329/2011, 40/2013, 222/2013, 168/2014, 22/2015, 230/2015).

When services exceed the notion of essential needs, the Court takes into exam, case by case, the existence of a reasonable correlation between the service and the residence requirement. Usually, the Court has considered in breach of the Constitution the requirement of qualified residence when it concerns foreigners exclusively, who are requested by the law to prove the regularity of their permanence in the country to benefit from a given service (inter alia, decisions No. 61/2011, 2/2013, 4/2013, 133/2013, 172/2013, 106/2018, 107/2018, 166/2018). When the residence requirement concerns both nationals and foreigners, in some cases the Courts has qualified the condition as indirect discrimination, especially if it has an unequal impact on foreigners (decisions No. 168/2014, 172/2013, 107/2018). In other cases the residence condition has been judged as in line with the constitutional principles (inter alia, decisions No. 222/2013, 141/2014, 50/2019).

\subsection{Concluding Considerations}

After decades of emigration, Italy has become the gateway to the European Union but also a country of destination for growing numbers of people in search of protection and better opportunities for themselves and their families. Contrary to the narrative of "the invasion" of Italy, the numbers of the foreign resident population results are in line with the European context, and data reveal that the growing presence of foreigners is not exclusively related to current international conflicts or crisis but also to a slow process of stabilisation of the migratory phenomenon seen over the last two decades. Decision-making and law-making, nonetheless, mainly respond to the "invasion" narrative as opposed to real data, so that the enforced new measures continue to be dedicated more to combating irregular immigration (and to the regularisation of undocumented migrants) and to guaranteeing public security, than to the integration of MRAs into Italian society.

Work is certainly among the most effective instruments for ensuring the effective integration of foreigners into the social fabric of the host country, but the labour market of foreigners has some peculiar characteristics. First, the complementarity with the labour market of Italians, which means that Italian workers can often afford to avoid certain occupations traditionally are considered unattractive (the so-called $d d d$, dirty, dangerous and demeaning jobs), and migrants undertake such unskilled 
jobs. Moreover, this suggests that the ideological rhetoric - dominant in the public debate on immigration - according to which migrants "steal jobs" is misleading (Allievi and Dalla Zuanna 2016: 12; Fondazione Leone Moressa 2017: 71). ${ }^{13}$ Second, the Italian labour market (for both nationals and foreigners) is segmented into regular and undeclared (or non-regular) work. The vastness of the phenomenon of foreigners' undeclared work certainly depends on a number of factors, many of which are of an extra-legal nature. However, the legal framework has its own responsibilities, with the Consolidated Law on Immigration that not only fails preventing and fighting the phenomenon, but in some cases tends to favour it (Sciarra and Chiaromonte 2014: 124-127).

Even though the Italian legal framework is in line with both EU legislation and the core labour standards recognized by the eight fundamental ILO Conventions, it remains disorganized and fragmented. Fundamental social rights are not always granted at the same conditions of Italian citizens, while some social welfare allowances can only be obtained through the intervention of the courts. Standards of care and assistance for asylum seekers and refugees vary considerably between the different centres of accommodation, so that the enjoyment of basic rights becomes "a matter of luck" (Oxfam 2017). As a result, harsh living conditions in overcrowded and self-organized settlements, illegal labour and exploitation represent a frequent outcome of the absence of efficient services supporting access to housing, employment, and more broadly to integration (Council of Europe, Commissioner for Human Rights 2011; UN Human Rights Council 2014).

Obstacles that hinder the full integration of foreigners into the Italian labour market take precendence over enablers, especially when foreign workers do not have a residence permit for work reasons but are instead beneficiaries of international and humanitarian protection. Since access to work for beneficiaries of international and humanitarian protection is still very complicated, there is a strong risk that the progressive reduction in the number of permits granted for work reasons and the simultaneous increase in the number of those granted for humanitarian reasons will slow down the process of integration through work. Moreover, the fact that it is generally possible to legally enter the country for work reasons only after having already found a job and not to look for a job, makes the already difficult process of integration even more complicated. Furthermore, particularly long and complicated administrative recruitment procedures would require a comprehensive review of the legislation to become instruments of social and economic integration and not of marginalization. The recently enacted measures to fight against labour exploitation and caporalato could be considered a valid contribution to the enhancement of workers' rights and dignity and a Italian best practice. Unfortunately, the law has not found full enforcement and it does not seem that the Italian legislator is currently devoting proper attention to this flaw in the original legislation.

\footnotetext{
${ }^{13}$ It is estimated that more than two thirds of foreigners work in unskilled professions, and only $6.7 \%$ in skilled professions. This is accompanied by the fact that they are often overeducated with respect to the working activities they carry out (37.4\% foreigners are overeducated compared to $22.2 \%$ of Italians) (Centro Studi e Ricerche IDOS, 2017)
} 
The Italian labour market needs foreign workers and entire sectors heavily rely on foreing workforce; Italians are reluctant to accept that foreign workers should stay for good, and the legal framework mirrors these contradictory visions.

\section{References}

Allievi, S., \& Dalla Zuanna, G. (2016). Tutto quello che non vi hanno mai detto sull'immigrazione. Roma-Bari: Laterza.

Ambrosini, M. (2001). La fatica di integrarsi: immigrati e lavoro in Italia. Bologna: Il Mulino.

Ambrosini, M. (2013). Immigration in Italy: Between economic acceptance and political rejection. Journal of International Migration and Integration, 14(1), 175-194.

Ambrosini, M. (2018). Irregular immigration in Southern Europe: Actors, dynamics and governance. London: Springer.

Ambrosini, M., \& Panichella, N. (2016). Immigrazione, occupazione e crisi economica in Italia. Quaderni di Sociologia, 72, 115-134.

Barbera, M., \& Guariso, A. (2019). La tutela antidiscriminatoria. Fonti, strumenti, interpreti. Torino: Giappichelli.

Biondi Dal Monte, F. (2013). Dai diritti sociali alla cittadinanza. La condizione giuridica dello straniero tra ordinamento italiano e prospettive sovranazionali. Torino: Giappichelli.

Calafà, L. (2017). Lavoro irregolare (degli stranieri) e sanzioni. Il caso italiano. Lavoro e diritto, $31(1), 67-90$.

Carrozza, P. (2016). Diritti degli stranieri e politiche regionali e locali. In C. Panzera, A. Rauti, C. Salazar, \& A. Spadaro (Eds.), Metamorfosi della cittadinanza e diritti degli stranieri. Napoli: Editoriale Scientifica. $57 \mathrm{ff}$.

Cavallaro, M., Diamanti, G., \& Pregliasco, L. (2018). Una nuova Italia: Dalla comunicazione ai risultati, un'analisi delle elezioni del 4 marzo. Roma: LIT EDIZIONI.

Centro Studi e Ricerche IDOS. (2017). Dossier statistico immigrazione 2017. Roma: IDOS.

Chiaromonte, W. (2008). Le prestazioni di assistenza sociale per i cittadini non comunitari ed il principio di non discriminazione. Una rassegna critica della giurisprudenza nazionale ed europea. Giornale Diritto del Lavoro e di Relazioni Industriali, 1, 101-145.

Chiaromonte, W. (2016). The Italian regulation on labour migration and the impact and possible impact of three EU directives on labour migration: Towards a human rights-based approach? In R. Blanpain, F. Hendrickx, \& P. H. Olsson (Eds.), National effects of the implementation of EU directives on labour migration from third countries. Alphen aan den Rijn: Kluwer Law International. $117 \mathrm{ff}$.

Chiaromonte, W. (2018). «Cercavamo braccia, sono arrivati uomini». Il lavoro dei migranti in agricoltura fra sfruttamento ed istanze di tutela, Giornale di diritto del lavoro e di relazioni industriali, 158, 321-356.

Chiaromonte, W. (2019). Ideologia e tecnica della disciplina sovranista dell'immigrazione. Protezione internazionale, accoglienza e lavoro dopo il "decreto Salvini”. Giornale di diritto del lavoro e di relazioni industriali, 162, 321-354.

Chiaromonte, W., \& Guariso, A. (2019). Discriminazioni e welfare. In M. Barbera \& A. Guariso (Eds.), La tutela antidiscriminatoria. Fonti, strumenti, interpreti. Torino: Giappichelli. $329 \mathrm{ff}$.

Colucci, M. (2018). Storia dell'immigrazione straniera in Italia. Dal 1945 ai giorni nostri. Roma: Carocci.

Corsi, C. (2014). Stranieri, diritti sociali e principio di eguaglianza nella giurisprudenza della Corte Costituzionale. Federalismi, 3/2014, 1-30. 
Corsi, C. (2018). Peripezie di un cammino verso l'integrazione giuridica degli stranieri. Alcuni elementi sintomatici. Associazione Italiana Costituzionalisti, Osservatorio costituzionale, 1.

Council of Europe. (2011). Report of the Commissioner for Human Rights. Available at: https:// www.coe.int/it/web/commissioner

D’Onghia, M., \& de Martino, C. (2018). Gli strumenti giuslavoristici di contrasto allo sfruttamento del lavoro in agricoltura nella legge $n$. 199 del 2016: ancora timide risposte a un fenomeno molto più complesso, Working Paper CSDLE “Massimo D'Antona”, 352/2018.

Diamanti, I. (2016). L'invasione mediale degli immigrati senza volto. IV Rapporto Carta di Roma, 9-13.

Direzione generale dell'immigrazione e delle politiche di integrazione - Ministero del lavoro e delle politiche sociali (2017). Settimo rapporto annuale. Gli stranieri nel mercato del lavoro in Italia. Roma.

EU Parliament, Directorate General for Internal Policies. (2016). Labour Market Integration of Refugees: Strategies and Good Practices. Available at: https://www.europarl.europa.eu/ RegData/etudes/STUD/2016/578956/IPOL_STU\%282016\%29578956_EN.pdf

Fanizza, F., \& Omizzolo, M. (2018). Caporalato. An authentic agromafia. Milano: Mimesis.

Favilli, C. (2015). Reciproca fiducia, mutuo riconoscimento e libertà di circolazione di rifugiati e richiedenti protezione internazionale nell'Unione europea. Rivista di diritto internazionale, 98(3), 701-747.

Federico, V., \& Pannia, P. (2019). Migrants' legal statuses in contemporary Italy. First attempts of conceptualization. Percorsi Costituzionali, 1(18), 17-36.

Fondazione Leone Moressa. (2017). Rapporto annuale sull'economia dell'immigrazione. La dimensione internazionale delle migrazioni. Bologna: Il Mulino.

Gaeta, L. (2014). Prima di tutto il lavoro. La costruzione di un diritto all'Assemblea Costituente. Roma: Ediesse.

Guariso, A. (2012). Senza distinzioni. Quattro anni di contrasto alle discriminazioni istituzionali nel Nord Italia. Quaderni di Apn, 2, 1-25.

Korkut, U., et al. (2013). The discourses and politics of migration in Europe. London: Springer.

OECD, ILO, the World Bank and IMF. (2016). Towards a Framework for Fair and Effective Integration of Migrants into the Labour Market. Available at: https://www.ilo.org/wcmsp5/ groups/public/\%2D\%2D-europe/\%2D\%2D-ro-geneva/\%2D\%2D-ilo-berlin/documents/genericdocument/wcms_556988.pdf

Oxfam. (2017). La lotteria dell'accoglienza. Il Sistema dell'emergenza permanente. Available at: https://www.oxfamitalia.org/wp-content/uploads/2017/11/La-Lotteria-Italia-dellaccoglienza_ Report-Oxfam_8_11_2017_Final.pdf

Sciarra, S., \& Chiaromonte, W. (2014). Migration status in labour and social security law. Between inclusion and exclusion in Italy. In C. Costello \& M. Freedland (Eds.), Migrants at work. Immigration and vulnerability in labour law. Oxford: Oxford University Press. $121 \mathrm{ff}$.

Testaì, P. (2015). "From the (e)migrant to the (im)migrant": The Italian nation-state and its migration rhetoric and history. Transnational Social Review, 5, 24-38.

Triandafyllidou, A., \& Ambrosini, M. (2011). Irregular immigration control in Italy and Greece: Strong fencing and weak gate-keeping serving the labour market. European Journal of Migration and Law, 13, 251-273.

UN Human Rights Council. (2014). Report by the Special Rapporteur on the human rights of migrants, Addendum: Follow-up mission to Italy, 2-6 December 2014. Available at: http:// www.refworld.org/docid/5576e8404.html 
Open Access This chapter is licensed under the terms of the Creative Commons Attribution 4.0 International License (http://creativecommons.org/licenses/by/4.0/), which permits use, sharing, adaptation, distribution and reproduction in any medium or format, as long as you give appropriate credit to the original author(s) and the source, provide a link to the Creative Commons license and indicate if changes were made.

The images or other third party material in this chapter are included in the chapter's Creative Commons license, unless indicated otherwise in a credit line to the material. If material is not included in the chapter's Creative Commons license and your intended use is not permitted by statutory regulation or exceeds the permitted use, you will need to obtain permission directly from the copyright holder.

(c) 